had boen issuod for fruit and vegetables to be washed and bread containing activated charcoal had been issued.

G. W. Clare gave a short history of the development of the decontamination service at Harwell. The building and plant, now in use, had paid for itself in only two years when costed on equipment which had been saved and put back into service. They moved everything by overhead tackle, which was much more satisfactory than trucking, and grid floors, with all services below, had been very successful. The centre is adjacent to the Active Waste Disposal Building and carries its own trained staff.
C. N. Davies

\title{
STRUCTURE AND FUNCTION OF LIPID-CONTAINING SYSTEMS
}

\section{A} JOINT meeting of the British Biophysical Society and the Biochemical Society attracted more than 200 participants to the University of Birmingham during April 20-21. A comprehensive survey of research relating to lipids and cell mombranes was undertaken in three sessions devoted to physical chemistry of lipid systems, composition and molecular structure of cell membranes, and the role of lipid in membrane activity.

An introductory talk by Dr. D. G. Dervichian on the general theme of the symposium was followed by 20 papers.

Information derived from X-ray diffraction (V. Luzzati) and infra-red spectroscopy (D. Chapman) served to emphasize the liquid crystalline nature of lipid layers under a variety of conditions and the complexity of phase relationships in mixed lipid systems. D. A.ttwood and L. Saunders, and D. B. Gammack, discussed the characteristics of dispersions of lipid in water as examined by lightscattering techniques, and A. D. Bangham and D. A Haydon the interpretation of birefringence measurements. J. A. Lucy and M. Glauert presented a molecular inter. pretation of their electron micrographs of negatively stained lipid preparations and diseussed its possible significance in relation to coll membrane structure.

A review by G. M. Gray of data on the compositions of a variety of cell membranos was followed by a report on the lipid components of membranous fractions from brain homogenates by J. Eichberg and R. M. C. Dawson. B. R. Malcolm presented evidence for the $\alpha$-helical con- figuration in protein layers at air-water interfaces and A. A. Eddy and P. Johns speculated about the possible arrangements of lipoprotoin sub-units in the red cell membrane. J. B. Finean summarized present views on the molecular structure of cell membranes and N. R. Silvester discussed the analysis of the romarkably detailed $\mathrm{X}$-ray diffraction patterns obtained from membrane material derived from eilia. P. F. Millington spoke of the various factors which influenced the widths and densities of lines which characterize cell membranes in electron micrographs, and R. Dourmashkin discussed correlations between the number of sites of interaction of immuno complexes with the surface of the red cell as seen in electron micrographs and the rate of lysis of the cells.

In the final session, J. N. Hawthorne undertook an assessment of present ideas on the role of individual phospholipid components in ion transport and A. D. Bangham and J. C. Watkins suggested that their obsorvations on the accumulation of ions inside lipid micelles might have some relovance to this problem. G. Hübscher discussed the problems associated with the assessment of the infuence of lipid components on the activities of enzyme systems and A. Martinosi presented biochemical and electron microscope data rolating to the inactivation and reactivation of muscle microsomes by removal and rostoration of the lecithin components. L. L. M. van Deenen summarized a variety of data relating to the metabolism of phospholipid fatty acids in cell membranes.

J. B. Finean

\section{RESEARCH EXPENDITURE AND INDUSTRY}

$I^{N}$ his presidential address to the twentieth annual general meeting of the Institution of Metallurgists on May 13, Dr. L. Rotherham dealt with the interrelationship of the growth of numbers of qualified scientists and technologists, the national economy as a whole, productivity and the proper expenditure on research and development. As such, his address was a noteworthy contribution. Although obviously directed to the metallurgist in the first place, it is worthy of close study by all concerned with the more general problems.

The new industries, such as electronics and man-made fibres, havo achieved commercial success by exploiting scientific and technological advances and in the process have ploughed back large sums for increasingly expensive researches. Thus during a period of time they have been able to produce and sell a succession of products. In contrast, some of the older industries have been relatively slow to adopt new techniques though the pace will probably quicken in the next fow years. The danger is that they will not put aside the money required to develop overbetter processes and products. In 1962 industry employed some 9 qualified men per $£$ I million of 'gross domostic product' outside the research and development depart. ments. In 1956 it had been 7.9, and on the basis of a 4 per cent economic growth and what appears to be a reasonably steady figure of 10.5 qualified men per $£ 1$ million of 'gross domestic product', an additional 100,000 scientists and technologists mav expect to find employment in industry between 1962 and 1970 . If all omployers, even the smaller, were to raise the number of 'qualified men' (that is, those with degrees, diplomas and those who take the examinations of professional institutions) employed to that of the highest percentage, almost half as many more would be needed. This increased number of scientists and technologists is seen by Dr. Rotherham as being increasingly provided by university graduates.

In 1961-62 about one-fifth of Britain's total qualified men were engaged on research and development, and if this ratio remains constant, between 1962 and 1970 , about 25,000 extra people will be required. The annual cost, on the average, is of the order of $£ 11,000$ per man engaged in such work, and for this increase a rise in productivity of some 3.8 per cent would suffice. The calculation, however, depends on the assumptions that research expenditure remains at the 1961-62 level of 2.7 per cent of the 'gross domestic product' and that research costs per man do not increase by more than 3 per cent per annum. In Dr. Rotherham's opinion, it might be prudent at this time to raise the percentage of the 'gross domestic product' devoted to research in order to counterbalance any shortfall in productivity, say, to 3 per cent (the American figure is already more than this). After making the usual allowances for rising costs, this should provide for an extra 6,000 research workers per annum. The 


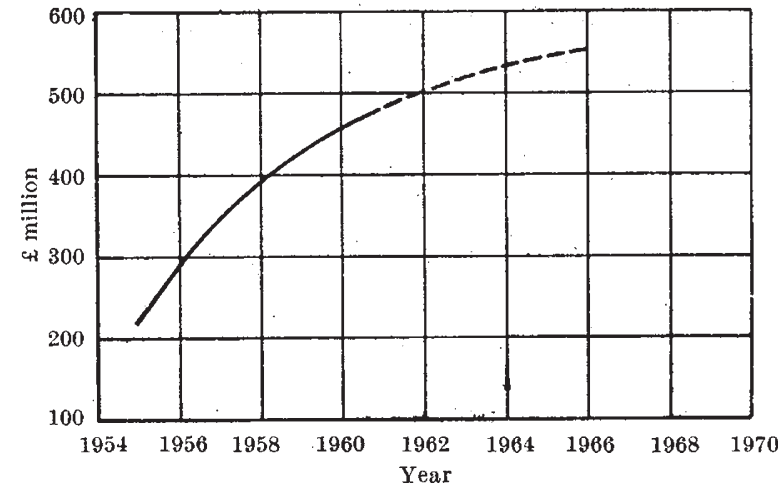

Fig. 1. Total British research expenditure (adjusted to take account of the fall in the value of the $\mathfrak{E}$ )

wisdom of this is further demonstrated by the graph of total expenditure on research and development, since 1955, which, as can be seen from Fig. 1, seems to be levelling off at $£ 550$ million per annum, and also this expenditure expressed as a percentage of the 'gross domestic product' where the graph suggests a levelling around $2 \cdot 8$ per cent (Fig. 2).

In the second half of his address, Dr. Rothorham was concerned with the prospects for metallurgists in the future and the part to be played by the professional institutions. The enhanced status of metallurgy, in which the universities have played a major part, is indicated by the fact that in 1962, despite the recession, only six men who graduated that year in the subject wero known to be still looking for jobs six months later. The immediate outlook is for about a 9 per cent increase per annum in the demand, even apart from increased employment in institutions of higher education and the special research expansion called for in the iron and steel industries.

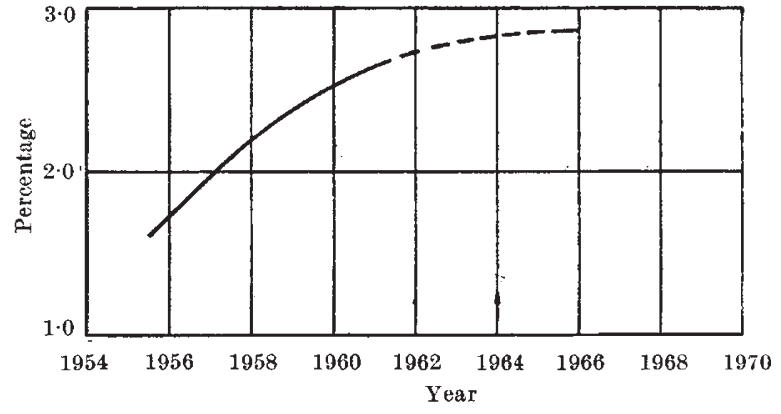

Fig. 2. Research expenditure as a percentage of the 'gross dcmestic product'

A pressing need is seen by Dr. Rotherham in effecting a better and more realistic image of the applied sciences to school children, their teachers and parents, and the public generally. In this the professional institutions can play a major part, especially since their function, with the increase of university graduates, will become less and less concerned with their own examinations.

It is concluded, therefore, that the numbers of men qualifying in science and engineering are increasing and will continue to increase within the foreseeable future. Membership of professional institutions is showing a corresponding growth. The full employment of these men is governed by industrial expansion and modernization, or putting it another way, commercially successful industries will need more qualified men to design, install and manage new plant. These industries will also provide the money, either directly or from taxes paid to the Exchequer, for increasingly expensive research and technological development. In contrast, any falling off in productivity will lead to a slowing up of plant modernization and research effort. Present indications are that industry will want all the qualified men it can get.

\section{FUNCTION OF AN INDUSTRIAL RESEARCH LABORATORY}

$\mathrm{T}$ HE above title poses questions which will always be controversial between scientists whether 'pure' or applied-since there are no precise answers. The points at issue will always hinge round the query whether an industrial laboratory should rightly embark on problems of academic interest, and vice versa. Can these two extremes be combined without detriment to both? The principal arguments are familiar. On one hand is the alleged ivory-tower complex of the academic scientist, isolating him from the practical realities of what he is investigating. On the other hand is the severely practical approach of the technologist, who is not allowed time or opportunity to wander into the by-ways of his subject, thereby perhaps missing new vistas which could lead to important discoveries. The giant industrial companies can, of course, afford to set up as independent establishments laboratories for fundamental research akin to those of the universities. At the other end of the scale the small company can afford to cater only for its day-today problems, and these inevitably are purely practical.

The problom therefore becomes of real significance with companies somewhere between these two extremes, and there are many in this category. The opening of New Butler's Court, Beaconsfield, Bucks, the Research Centre of the Wiggins Teape Group of papermakers, on March 20, 1963 , following a visit of inspection by the Duke of Edinburgh on the previous day, directs attention to a particular case of this kind. Butler's Court, as purchased by the Company in 1956 on the site of Edmund Burke's former home, provided $13,500 \mathrm{ft}^{2}{ }^{2}$ of laboratory space. Since then a further $19,000 \mathrm{ft} .{ }^{2}$ of laboratories and pilot plant buildings have been erected, and the above occasion was the inauguration of these by the chairman, Mr. L. Farrow.

Wiggins Teape are papermakers and paper converters operating, in the United Kingdom alone, 15 actual paper mills and 15 factories where associated manufactures are carried on. Although the general research requirements of the paper industry are handled by the British Paper and Board Industry Research Association which the Wiggins Teape Group supports, the Company has perhaps more specialized problems than any other of its kind, since it manufactures speciality papers and in particular the so-called 'industrial papers'. Examples are: papers for impregnation with plastics, photographic base papers, leather papers, photo-copying and other copying papers, and chart papers resistant to water and oil. These, of course, are in addition to the usual types of high-grade writings and printings, and speciality wrappings such as vegetable parchment and glassine.

With a wide and varied production of this nature the interface between pure and applied science becomes increasingly diffuse. However, Dr. H. F. Rance, technical director, recently summed up the policy of his company quite unambiguously by pointing out that research and development are regarded as a business activity which must show returns commensurate with expenditure. Since they exist to promote change, in the interest of the 